\title{
ДОМІНАНТНІ ПСИХОЛОГІЧНІ ЧИННИКИ ГОТОВНОСТІ ДО ЗМІН СЕРЕД МАЙБУТНІХ УКРАЇНСЬКИХ ПРАВООХОРОНЦІВ
}

\author{
Стояцька Ганна \\ Дніпровська академія неперервної освіти, \\ м. Дніпро, Україна \\ a.sagdianna@gmail.com \\ ORCID: https://orcid.org/0000-0002-6501-6703
}

Мета. Стаття презентує пошук концептуальних динамічних чинників, які визначають i спричиняють конфігурацію психологічної готовності до сприйняття змін серед нового покоління українських поліцейських. У статті представлено результати продовження дослідження психологічної готовності до змін серед майбутніх українських правоохоронців.

Методи. На цьому етапі дослідження було проведено регресійний аналіз показників за 8 методиками дослідження. Метод побудови моделі множинної лінійної регресії - метод найменших квадратів.

Результати. Основні результати дослідження - це здійснення покрокового регресійного аналізу 13 психологічних показників, які можуть визначати таку психологічну властивість як готовність до змін. Аналіз підтвердив концептуальну гіпотезу про наявність ієрархічно зумовлених ступенів причинно-наслідкового зв'язку між готовністю до змін та різними сторонами професійної мотивації, відкритості до нового досвіду, мотивації до успіху, соціальної адаптивності. Коефіцієнт детермінації $\left(\mathrm{R}^{2}\right)$ отриманої оптимальної регресійної моделі становить $65,54 \%$. Це означає, що саме на такий відсоток готовність до змін визначається психологічними показниками, обраними для дослідження. Було проаналізовано коефіцієнти регресії та підраховано коефіцієнти еластичності отриманої моделі. Домінантними чинниками у формуванні готовності до сприйняття змін серед майбутніх поліцейських визначено такі показники як: зовнішня позитивна мотивація, внутрішня мотивація та відкритість до нового досвіду. Найменш значущі чинники, котрі зумовлюють готовність до змін у цьому соціальному середовищі - це толерантність до двозначності, рівень психологічного благополуччя та мислення зростання.

Висновки. Загалом майбутніх правоохоронців можна вважати цілком сприятливим соціальним середовищем для вивчення феномену готовності до змін. Мотиваційний комплекс та спрямованість на набуття нового досвіду

ISSN 2308-3743 (Online), ISSN 2227-1376 (Print)

(C) Стояцька Г., 2021. Ця стаття відкритого доступу на умовах CC BY-NC 4.0 
визнані ключовими психологічними чинниками формування готовності до змін для цієї професійної групи.

Ключові слова: внутрішня мотивація, зовнішня позитивні мотивація, відкритість до нового досвіду, регресійний аналіз, управління змінами, прихильність до змін, індивідуальна готовність до змін, організаційні зміни.

Stoyatska Ganna. Dominant Psychological Factors of Readiness For Change Among Future Ukrainian Law Enforcement Officers.

Purpose. Search for conceptual dynamic conditions determining and causing the psychological readiness configuration to perceive change among the new generation of Ukrainian police officers is done in this paper. The article presents the results of the study dedicated to the issues of psychological readiness for change among future Ukrainian law enforcement officers. The beginning of this study as well as the factor analysis results are offered in the previous publication.

Methods. Measure regression analysis was performed according to 8 research methods at this stage of the study. The method of constructing a multiple linear regression model is the method of the least squares. Criteria used are the following: F-criterion for establishing a linear connection to test the null hypothesis, $t$ regression coefficients' check criterion, Ramsey test for statistical significance of the multiple linear regression model and the correctness of its functional dependence verification, Chow test for structural stability model's presence or absence.

Results. The main results of the study include the implementation of step-bystep regression analysis of 13 psychological indicators determining such a psychological property as readiness for change. The analysis confirmed the conceptual hypothesis of the existence of hierarchically determined degrees of causality between the willingness to change and various aspects of professional motivation, openness to new experiences, motivation for success, and social adaptability. The coefficient of determination $\left(\mathrm{R}^{2}\right)$ of the optimal regression's model obtained was $65.54 \%$. This means that it is this percentage of readiness for change that is determined by the psychological indicators selected for the study. The regression coefficients were analyzed and the obtained model elasticity coefficients were calculated. The dominant factors in the formation of readiness to accept change among future police officers are such marks as external positive motivation, internal motivation and openness to new experiences. Tolerance to ambiguity, psychological well-being level and growth mindset are defined as the least significant factors determining readiness for changes in this social environment.

Conclusions. In general, future law enforcement officers can be considered a very favorable social environment for the readiness for change phenomenon studying. The motivational complex and the new experience gaining trend are recognized as the key psychological factors in formation of readiness for change for this professional group.

Key words: internal motivation, external positive motivation, openness to new experience, regression analysis, change management, commitment to change, individual readiness for change, organizational change. 


\section{Стояцкая Анна. Доминантные психологические факторы готовности к изменениям среди будущих украинских правоохранителей.}

Цель. В данной работе осуществляется поиск концептуальных динамических факторов, которые определяют и влекут за собой конфигурацию психологической готовности к восприятию изменений среди нового поколения украинских полицейских. В статье представлены результаты продолжения исследования психологической готовности к изменениям среди будущих украинских правоохранителей.

Методы. На данном этапе исследования был регрессионный анализ показателей по 8 методикам исследования. Метод построения модели множественной линейной регрессии - метод наименьших квадратов.

Результаты. К основным результатам исследования можно отнести пошаговый регрессионный анализ 13 психологических показателей, которые могут определять такое психологическое свойство как готовность к изменениям. В ходе анализа получила подтверждение концептуальная гипотеза о наличии иерархически обусловленных степеней причинно-следственной связи между готовностью к изменениям и разными сторонами профессиональной мотивации, открытости новому опыту, мотивации к успеху, социальной адаптивности. Коэффициент детерминации (R2) полученной оптимальной регрессионной модели составил $65,54 \%$. Это означает, что именно на такой процент готовность к изменениям определяется психологическими показателями, отобранными для исследования. Были проанализированы коэффициенты регрессии и подсчитаны коэффициенты эластичности полученной модели. Доминирующими факторами в формировании готовности к восприятию изменений среди будущих полицейских определены такие показатели, как внешняя положительная мотивация, внутренняя мотивация и открытость нового опыта. Наименее значимыми факторами, обусловливающими готовность к изменениям в этой социальной среде, определены толерантность к двусмысленности, уровень психологического благополучия и мышления роста.

Выводы. В общем, будущих правоохранителей можно считать вполне благоприятной социальной средой для изучения феномена готовности к изменениям. Мотивационный комплекс и направленность на обретение нового опыта признаны ключевыми психологическими факторами формирования готовности к изменениям данной профессиональной группы.

Ключевые слова: внутренняя мотивация, внешняя положительная мотивация, открытость нового опыта, регрессионный анализ, управление изменениями, приверженность изменениям, индивидуальная готовность к изменениям, организационные изменения.

Вступ. Актуальність проведення дослідження зумовлена необхідністю всебічного вивчення та подальшого вдосконалення психологічної складової процесу підготовки поліцейських в Україні. 
Як вже було зазначено в результатах попереднього етапу цього дослідження (Стояцька Г., 2021), групою для спостереження стали курсанти закладів вищої освіти зі специфічними умовами навчання спеціальності «Правоохоронна діяльність» (поліцейські), яких готують за освітньо-професійною програмою «2 роки курсант - 1 рік слухач» (Наказ МВС, 2019). У серпні 2021 року Міністерство внутрішніх справ прийняло рішення про завершення цього освітнього експерименту та припинення провадження освітньої діяльності за цією освітньо-професійною програмою (Наказ МВС, 2021). Тож це дослідження є свого роду унікальним, адже експеримент з підготовки фахівців, що тривав три роки, наразі завершено і випускниківполіцейських, які навчалися за подібною програмою, у найближчому майбутньому не передбачено. Така ситуація дає підстави проаналізувати результати цього освітнього експерименту, передбачити його можливі наслідки, зокрема i 3 точки зору психологічної особливості сприйняття змін.

Мета цього етапу дослідження - доведення концептуальної гіпотези про існування обмеженого числа домінантних психологічних чинників у структурі такої психічної характеристики як готовність до змін та існування причинно-наслідкового зв'язку між ними.

Під час поглибленого вивчення специфічних рис обраної соціальної групи було сформульовано завдання дослідження: здійснити регресійний аналіз масиву даних 3 метою виокремлення найбільш домінантних психологічних чинників, що зумовлюють сприйняття змін досліджуваними. Саме покроковий регресійний аналіз дає змогу найчіткіше продемонструвати різну вагу окремих психологічних чинників у структурі певної психологічної риси. Водночас саме регресія дозволяє побудувати достатньо чіткі прогнози щодо можливої динаміки досліджуваного показника (в нашому випадку - готовності до змін) залежно від імовірної динаміки окремих компонентів (факторів), які його спричиняють.

Методи та процедура дослідження. Метод побудови моделі множинної лінійної регресії - метод найменших квадратів. Застосовані критерії: F-критерій встановлення лінійного зв'язку для перевірки нульової гіпотези, t-критерій перевірки коефіцієнтів регресії, тест Ремзі для перевірки статистичної значущості моделі множинної лінійної регресії та правильності їі функціональної залежності, тест Чоу на наявність або відсутність структурної 
стабільності моделі.

Обговорення результатів. Готовність до змін у найсучасніших дослідженнях постає як мультипроблемне психологічне явище. Найактивніше воно досліджується в контексті вивчення питань трансформаційного лідерства (як підтримка змін, відкритість до змін, опір змінам) (Peng, Li, Wang \& Lin, 2021), а також у площині бізнессередовища та управління, поведінкових паттернів різних соціальних груп, зокрема і працівників організацій (Rehman, Mahmood, Ibtasam, Murtaza \& other, 2021), (Qiao, Da, Li, Zhou \& other, 2021), (Ahmad, Liu \& Butt, 2020), (Myklebust, Motland, Garnås, Bjørklund \& other, 2020), (Olafsen, Nilsen, Smedsrud \& Kamaric, 2020), (Augustsson, Richter, Hasson \& von Thiele Schwarz, 2017), пацієнтів різноманітних закладів лікування або відвідувачів закладів превенції (Knight, Joe, Becan, Crawley \& other, 2019), (Augustsson, Richter, Hasson \& von Thiele Schwarz, 2017).

Широкий науковий контекст вивчення готовності до змін також очевидний у зв'язку з проблемою особистісного зростання (Weigold, Weigold, Russell, Wolfe \& other, 2020), (Zaman \& Naqvi, 2020), способом подолання бар'єрів на шляху до самореалізації (Jungers \& Gregoire, 2021), отримання головного супутнього результату на шляху до успіху та заохочення (Encouragement: The essential element of helping, 2019).

Найчастіше йдеться про розуміння ролі контекстуальних та індивідуальних факторів у поясненні різних типів прихильності до організаційних змін, зокрема, шляхом вивчення відмінності між гнучкою та стабільною організаційною культурою (Olafsen, Nilsen, Smedsrud \& Kamaric, 2020). Саме тому вивчення цього явища на прикладі здобувачів фаху і майбутніх поліцейських видається таким, що може мати продуктивні наслідки для вдосконалення корпоративної культури та покращення психологічного клімату в організації.

Дані щодо вибірки, використаних методик та процедури дослідження детально викладено в попередній статті, яка також йому присвячена. Принагідно зазначимо, що до моделі регресії ввійшли дані за 13 показниками 38 психодіагностичних методик (Стояцька Г., 2021, с. 217).

Якщо в першій частині дослідження готовність до змін визначалася через зниження розмірності низки детермінантних 
змінних через об'єднання їх у набори компонентів шляхом факторного аналізу, то в цій частині здійснено визначення основних домінантних психологічних чинників у структурі цієї риси. Дані щодо нормальності розподілу показників $є$ прийнятними для лінійного регресійного аналізу.

Надзвичайно інформативними є дані, які демонструють процес регресування досліджуваних показників (предикторів). Результати представлено в таблиці 1.

Табличя 1

Динаміка регресії 12 предикторів відносно досліджуваного показника (готовність до змін)

\begin{tabular}{|c|c|c|c|c|}
\hline № моделі & $\begin{array}{c}\text { число } \\
\text { змінних } \\
\text { (предикторів) }\end{array}$ & $\begin{array}{r}\text { число } \\
\text { значимих } \\
\text { факторів }\end{array}$ & $\begin{array}{l}\text { показник, що } \\
\text { регресував }\end{array}$ & $\begin{array}{c}\text { коефіціснт } \\
\text { детермінації } \\
\text { (відсоток } \\
\text { дисперсії) }\end{array}$ \\
\hline $\begin{array}{l}\text { модель № } \\
12\end{array}$ & 1 & 1 & $\begin{array}{l}\text { зовнішня позитивна } \\
\text { мотивація }\left(\mathrm{X}_{9}\right)\end{array}$ & $55,26 \%$ \\
\hline $\begin{array}{l}\text { модель № } \\
11 \\
\end{array}$ & 2 & 2 & $\begin{array}{l}\text { внутрішня мотивація } \\
\left(\mathrm{X}_{7}\right)\end{array}$ & $62,23 \%$ \\
\hline $\begin{array}{l}\text { модель № } \\
10\end{array}$ & 3 & 3 & $\begin{array}{l}\text { відкритість до нового } \\
\text { досвіду }\left(\mathrm{X}_{10}\right)\end{array}$ & $65,54 \%$ \\
\hline модель № 9 & 4 & 3 & $\begin{array}{c}\text { мотиваційний комплекс } \\
\left(\mathrm{X}_{6}\right)\end{array}$ & $66,48 \%$ \\
\hline модель № 8 & 5 & 3 & $\begin{array}{c}\text { зовнішня негативна } \\
\text { мотивація }\left(\mathrm{X}_{8}\right)\end{array}$ & $67,30 \%$ \\
\hline модель № 7 & 6 & 4 & $\begin{array}{c}\text { соціальна адаптивність } \\
\left(\mathrm{X}_{12}\right)\end{array}$ & $68,11 \%$ \\
\hline модель № 6 & 7 & 4 & адаптивність $\left(\mathrm{X}_{2}\right)$ & $68,89 \%$ \\
\hline модель № 5 & 8 & 4 & $\begin{array}{l}\text { мотивація до успіху } \\
\left(\mathrm{X}_{11}\right) \\
\end{array}$ & $69,24 \%$ \\
\hline модель № 4 & 9 & 4 & $\begin{array}{c}\text { загальна інновативність } \\
\left(\mathrm{X}_{1}\right)\end{array}$ & $69,40 \%$ \\
\hline модель № 3 & 10 & 3 & $\begin{array}{c}\text { мислення зростання та } \\
\text { імпліцитні інтенції }\left(\mathrm{X}_{4}\right)\end{array}$ & $69,57 \%$ \\
\hline модель № 2 & 11 & 2 & $\begin{array}{c}\text { рівень психічного } \\
\text { благополуччя }\left(\mathrm{X}_{5}\right)\end{array}$ & $69,64 \%$ \\
\hline модель № 1 & 12 & 2 & $\begin{array}{l}\text { толерантність до } \\
\text { двозначності }\left(\mathrm{X}_{3}\right)\end{array}$ & $69,68 \%$ \\
\hline
\end{tabular}

У моделях № 10, 11 та 12 всі змінні мали статус значущих ознак. Але саме модель №10 виявилася моделлю 3 трьома показниками, pзначення кожного з яких було $<0,05$. Середня помилка апроксимації цієї моделі становить 7,926, показник $\mathrm{R}^{2}$ (сумарної проясненої дисперсії) - 65,54 \%. Тому саме ii було залишено як робочу модель для подальшої інтерпретації. Фактично на десятому кроці множинної лінійної регресії ми отримали модель, у якій досліджуваний показник 
(готовність до змін) визначили трьома найпотужнішими незалежними змінними $-\mathrm{X}_{9}$ (зовнішня позитивна мотивація), $\mathrm{X}_{7}$ (внутрішня мотивація) та $\mathrm{X}_{10}$ (відкритість до нового досвіду), які сумарно прояснюють дисперсію вибірки на 65,54\%. Водночас інші 9 досліджуваних незалежних змінних сумарно додавали до дисперсійної статистики моделі ще 4,14 \%, а частина непроясненої моделлю дисперсії становила $30,32 \%$ (тобто 30,32\% ознак, не врахованих у моделі взагалі).

Після проведених підрахунків постала необхідність перевірити отриману оптимальну модель на наявність або відсутність структурної стабільності. В досліджуваній характеристиці (готовність до змін) було виокремлено наявний групувальний показник рівня проявленості: 62 показники зі 103 розташувалися вище за медіанне значення (високий/вище від середнього рівня), решта показників вибірки - нижче від медіанного значення (нижче від середнього/низький рівні). За допомогою тесту Чоу було здійснено т.зв. розщеплення вибірки на основі медіанного показника залежної змінної, тобто за 50-м процентилем. Отримані результати свідчать, що вірогідність прийняття нульової гіпотези (відсутність структурних зрушень) = 5,01288e-012 (тобто набагато менше 0,05). Отож, результати тесту та модифікованої регресії тесту Чоу дають підстави зробити висновок, що за показником рівня проявленості властивостей готовності до змін у нашій вибірці існує структурна нестабільність. На результати регресії значно вплинула та частина вибірки, в якій досліджувана риса проявлена на високому та вище від середнього рівнях. Це означає, що в майбутньому для вдосконалення та розвитку цієї психічної характеристики $є$ підстави більш ретельно досліджувати спостереження зі значеннями вище від медіанного як більш інформативні.

Згодом було проаналізовано дисперсійну статистику, коефіцієнти еластичності моделі, а також інтерпретацію можливих змін, яких зазнаватиме показник готовності до змін за умов динаміки трьох значущих незалежних змінних. Аналіз дисперсійної статистики наведено в таблиці 2. 


\section{Табличя 2}

Показники загальної проясненої дисперсії на початку та наприкінці побудови множинної лінійної регресії

\begin{tabular}{|l|c|ccc|}
\hline Коефіцієнт детермінації & Відсоток & \multicolumn{4}{|c|}{ Показник } \\
\hline $\mathrm{R}^{2} 12$ & $69,68 \%$ & $\begin{array}{c}\text { сукупна доля впливу 12 незалежних } \\
\text { змінних }\end{array}$ \\
\hline $1-\mathrm{R}^{2} 12$ & $30,32 \%$ & $\begin{array}{c}\text { доля впливу не врахованих у моделі } \\
\text { змінних }\end{array}$ \\
\hline $\mathrm{R}^{2} 3$ & $65,54 \%$ & $\begin{array}{c}\text { сукупна доля впливу 3х значимих } \\
\text { змінних }\end{array}$ \\
\hline $\mathrm{R}^{2} 14-\mathrm{R}^{2} 3$ & $4,14 \%$ & $\begin{array}{c}\text { сукупна доля впливу 9 регресованих } \\
\text { змінних }\end{array}$ \\
\hline
\end{tabular}

Наступний крок - аналіз коефіцієнтів регресії значущих змінних (ознак). Коефіцієнт регресії показує, на скільки змінюватиметься Y (залежна змінна) за умов збільшення якоїсь змінної $\mathrm{X}_{7}, \mathrm{X}_{9}, \mathrm{X}_{10}$ на одиницю виміру тієї або іншої ознаки. Результати аналізу коефіцієнтів регресії нашої оптимальної множинної регресійної моделі представлено в таблиці 3.

Таблиця 3

\section{Показники коефіціснтів регресії}

\begin{tabular}{|c|c|c|c|}
\hline $\begin{array}{l}\text { Незалежна } \\
\text { змінна }\end{array}$ & $\begin{array}{r}\text { Коефіці } \\
\text { єнт регресії }\end{array}$ & $\begin{array}{c}\text { Показни } \\
\text { к } \\
\text { коефіцієнту } \\
\text { регресії } \\
\end{array}$ & Значущість \\
\hline $\begin{array}{c}\text { Внутрішня } \\
\text { мотивація }(x 7)\end{array}$ & b7 & 3,08865 & $\begin{array}{l}\text { Готовність до змін зростатиме на } 3,08 \text {, } \\
\text { якщо на одну одиницю виміру зростатиме } \\
\text { внутрішня мотивація }\end{array}$ \\
\hline $\begin{array}{c}\text { Зовнішня } \\
\text { позитивні } \\
\text { мотивачія }(x 9)\end{array}$ & b9 & 3,38810 & $\begin{array}{l}\text { Готовність до змін зростатиме на } 3,38 \text {, } \\
\text { якщо на одну одиницю виміру зростатиме } \\
\text { зовнішня позитивна мотивація }\end{array}$ \\
\hline $\begin{array}{l}\text { Відкритість } \\
\text { до нового } \\
\text { досвіду } \\
(\text { х10) }\end{array}$ & b10 & 0,13504 & $\begin{array}{l}\text { Готовність до змін зростатиме на } 0,13 \text {, } \\
\text { якщо на одну одиницю виміру зростатиме } \\
\text { показник відкритості до нового досвіду }\end{array}$ \\
\hline
\end{tabular}

За умови визначення в регресії трьох значущих ознак можна перерахувати їх попарну кореляцію зі змінною Ү без урахування впливу третьої (табл. 4). Оскільки в моделі є три незалежні змінні, які найбільшою мірою визначають досліджуваний показник готовності до змін, то можна скласти загалом шість варіантів комбінацій між цими змінними та досліджуваним показником. Аналіз цієї статистики здатен продемонструвати внесок i вплив кожної 3 незалежних змінних на кореляцію залежної змінної з двома іншими. Таким чином можна спрогнозувати те, як змінюватиметься кореляція між 
показником готовності до змін з іншими показниками у разі, якщо ми виключатимемо якусь одну з незалежних змінних. Так, кореляція між готовністю до змін (Y) та зовнішньою позитивною мотивацією (Х9) зміниться на 0,47 , якщо забрати із співвідношення показник відкритості до нового досвіду $\left(\mathrm{X}_{10}\right)$.

Табличяя 4

Аналіз парних коефіціснтів кореляції залежної змінної з кожною 3 незалежних змінних без урахування третьої

\begin{tabular}{|c|r|r|c|}
\hline Залежність між змінними & $\begin{array}{r}\text { Доля } \\
\text { впливу }\end{array}$ & $\begin{array}{c}\text { Різни } \\
\text { ця }\end{array}$ & Значущість \\
\hline $\mathrm{rYX}_{9}$ без врахування впливу $\mathrm{X}_{10}$ & 0,47 & $-0,27$ & значна доля впливу $\mathrm{X}_{10}$ \\
\hline $\mathrm{rYX}_{9}$ без врахування впливу $\mathrm{X}_{7}$ & 0,61 & $-0,13$ & $\mathrm{X}_{7}$ \\
\hline $\mathrm{rYX}_{7}$ без врахування впливу $\mathrm{X}_{9}$ & 0,39 & $-0,24$ & значна доля впливу $\mathrm{X}_{9}$ \\
\hline $\mathrm{rYX}_{7}$ без врахування впливу $\mathrm{X}_{10}$ & 0,43 & $-0,20$ & значна доля впливу $\mathrm{X}_{10}$ \\
\hline $\mathrm{rYX}_{0}$ без врахування впливу $\mathrm{X}_{7}$ & 0,48 & $-0,18$ & значна доля впливу $\mathrm{X}_{7}$ \\
\hline $\mathrm{rYX}_{10}$ без врахування впливу $\mathrm{X}_{9}$ & 0,51 & $-0,15$ & $\mathrm{X}_{9}$ \\
\hline
\end{tabular}

Показники підтверджують, що кожна 3 трьох значущих ознак володіє значною та досить значною долею впливу. Тобто всі три значущі незалежні змінні в структурі такої характеристики як готовність до змін відіграють суттєву роль.

Крім цього, було здійснено аналіз коефіцієнтів еластичності, що демонструють те, як зміниться досліджуваний показник Y відносно предикторів $\mathrm{X}_{7}, \mathrm{X}_{9}, \mathrm{X}_{10} \mathrm{y}$ разі $\ddot{\mathrm{ix}}$ зміни на $1 \%$ ). Коефіцієнти еластичності становили відповідно: для $\mathrm{X}_{7}$ (внутрішня мотивація) 0,363, для $\mathrm{X}_{9}$ (зовнішня позитивна мотивація) - 0,299, для $\mathrm{X}_{10}$ (відкритість до нового досвіду) - 0,224. Тобто всі значення еластичності предикторів, що є значущими в нашій моделі, менше 1, що означає нееластичність будь-якого з них щодо залежної змінної лише всі вони спільно можуть визначати еластичність готовності до змін. Це означає, що за умови змін окремо показників зовнішньої позитивної мотивації, внутрішньої мотивації або відкритості до нового досвіду не відбуватиметься суттєвих змін у показнику готовності до змін.

Оскільки модель множинної лінійної регресії будується не лише для визначення найбільш впливових факторів, що визначають та прояснюють найбільшу долю дисперсії вибірки дослідження, але й для прогнозування того, як поводитиметься залежна змінна за умов динаміки впливових предикторів (незалежних змінних), було 
побудовано графіки діаграм розсіювання (scatter plots). На них продемонстровано, як співвідносяться залежний показник $\mathrm{Y}$ (готовність до змін) з найбільш впливовим предиктором $\mathrm{X}_{9}$ (зовнішня позитивна мотивація) на останньому етапі множинної лінійної регресії $\left(\mathrm{R}^{2}=0,5526\right)$ (рис. 1$)$ та на стадії прогнозу $\left(\mathrm{R}_{2}=1\right)$ (рис. 2$)$.



Рис. 1. Діаграма розсіювання спостережуваних показників залежної змінної «Готовність до змін» та найбільш значущої змінної «зовнішня позитивна мотивація»

Діаграми розсіювання наочно демонструють те, якими б могли бути показники готовності до змін у досліджуваних вибірки, якби наша модель мала $\mathrm{R}^{2}=1$, тобто описувала би всі $100 \%$ дисперсії нашої вибірки.

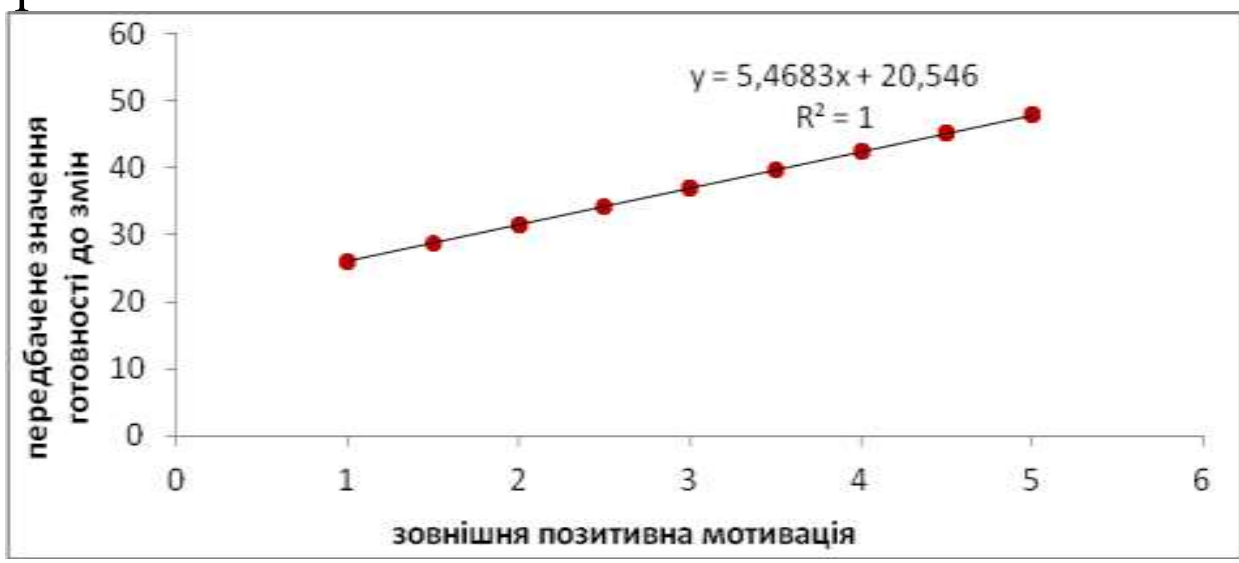

Рис. 2. Діаграма розсіювання прогнозованих показників залежної змінної «готовність до змін» та найбільш значущої змінної «зовнішня позитивна мотивація»

Отже, врахувавши всі нюанси множинного регресійного аналізу, можна зробити на його основі такі висновки:

1) у множинну лінійну регресію ввійшло 13 змінних (досліджувана залежна змінна $\mathrm{Y}$ (готовність до змін) та 12 пояснювальних змінних, визначених під час аналізу матриці 
кореляційних коефіцієнтів). Упродовж усіх етапів дослідження tстатистика свідчила, що між досліджуваною змінною та, принаймні, однією з незалежних змінних $\mathrm{X}_{1}-\mathrm{X}_{12}$ існує стійкий лінійний зв'язок, $\mathrm{a}$, отже, побудова регресійної моделі виправдана;

2) 312 отриманих моделей лінійної регресії ми обрали одну - 3 трьома значущими ознаками та сукупною поясненою дисперсією $65,54 \%$. Найвищим показником значущості у вибірці володіє ознака $\mathrm{X}_{9}$ «зовнішня позитивна мотивація» - 3 власним показником дисперсії 55,26 \%. Значною часткою впливу також володіють змінні $\mathrm{X}_{7}$ «внутрішня мотивація» та $\mathrm{X}_{10}$ «відкритість до нового досвіду»;

3) частина непроясненої моделлю дисперсії становить 30,32\%. Це означає, що існує 30,32 \% досліджуваної змінної «готовність до змін», які визначаються ознаками, не врахованими в нашому дослідженні;

4) перераховані показники парних коефіцієнтів кореляції трьох значущих змінних свідчать про те, що показники зовнішньої позитивної мотивації та внутрішньої мотивації володіють дуже високим рівнем впливу на показник готовності до змін, а показник відкритості до нового досвіду - високим рівнем впливу;

5) аналіз коефіцієнтів еластичності свідчить, що залежна змінна не $\epsilon$ еластичною щодо жодної з трьох незалежних змінних. Лише всі три - одночасно, в сукупності здатні визначати еластичність такої психічної характеристики як готовність до змін.

Висновки i перспективи. Побудована модель множинної лінійної регресії дала змогу виділити найбільш значущі чинники, що прояснюють готовність до змін серед майбутніх правоохоронців, а саме: показники зовнішньої позитивної мотивації, внутрішньої мотивації, відкритості до нового досвіду. Отримані дані демонструють, що до лав Національної поліції приходять молоді люди, найбільш мотивовані суспільною вагою професії, соціальним престижем та привабливістю, особливостями корпоративної субкультури правоохоронців, матеріальним благополуччям, бажанням працювати в команді, бажанням бодай на певний час присвятити життя типу діяльності, яка хоч і 3 високим ступенем ризику, але в змозі надати певну соціальну стабільність. Загалом виокремлення такого набору чинників дає змогу якісніше формувати кадрову політику та трансформувати уявлення про роль та значення готовності до змін, інноваційності, мислення зростання у професійній 
діяльності правоохоронця. Адже готовність до змін - це також і вміння послуговуватись сучасними рішеннями під час здійснення правоохоронних функцій, здатність до гнучкості у світі, де локальні та глобальні виклики перманентно вимагають швидкості реагування.

\section{Література}

1. Ahmad, A. B., Liu, B., \& Butt, A. S. (2020). Scale development and construct clarification of change recipient proactivity. Personnel Review, 49(8), 1619-1635. https://doi.org/10.1108/PR-02-2019-0091

2. Augustsson, H., Richter, A., Hasson, H., \& von Thiele Schwarz, U. (2017). The need for dual openness to change: A longitudinal study evaluating the impact of employees' openness to organizational change content and process on intervention outcomes. Journal of Applied Behavioral Science, 53(3), 349-368. https://doi.org/10.1177/0021886317691930

3. Encouragement: The essential element of helping. (2019). Adlerian counseling and psychotherapy: A Practitioner's wellness approach, sixth edition (pp. 84-114) https://doi.org/10.4324/9781351038744

4. Jungers, C., \& Gregoire, J. (2021). Confrontation: A dialectical humanistic consideration. Journal of Humanistic Counseling, 60(1), 58-75. https://doi.org/10.1002/johc.12151

5. Knight, D. K., Joe, G. W., Becan, J. E., Crawley, R. D., Theisen, S. E., \& Flynn, P. M. (2019). Effectiveness of an intervention for improving intrinsic motivation among adolescent males in a secure substance use treatment setting. Criminal Justice and Behavior, 46(1), 101-114. https://doi.org/10.1177/0093854818804857

6. Myklebust, T., Motland, K., Garnås, A., Bjørklund, R., Bjørkli, C., \& Fostervold, K. I. (2020). An empirical evaluation of the relationship between human relations climate and readiness for change. Scandinavian Journal of Work and Organizational Psychology, 5(1), 1-12. https://doi.org/10.16993/SJWOP.74

7. Olafsen, A. H., Nilsen, E. R., Smedsrud, S., \& Kamaric, D. (2020). Sustainable development through commitment to organizational change: The implications of organizational culture and individual readiness for change. Journal of Workplace Learning, 33(3), 180-196. https://doi.org/10.1108/JWL-05-2020-0093

8. Peng, J., Li, M., Wang, Z., \& Lin, Y. (2021). Transformational leadership and employees' reactions to organizational change: Evidence from a metaanalysis. Journal of Applied Behavioral Science, 57(3), 369-397. https://doi.org/10.1177/0021886320920366

9. Qiao, S., Da, W., Li, X., Zhou, Y., \& Shen, Z. (2021). Occupational stress, burnout, and organizational readiness for change: A longitudinal study among HIV HCPs in china. Psychology, Health and Medicine, https://doi.org/10.1080/13548506.2021.1903059

10. Rehman, N., Mahmood, A., Ibtasam, M., Murtaza, S. A., Iqbal, N., \& Molnár, E. (2021). The psychology of resistance to change: The antidotal effect of 
organizational justice, support and leader-member exchange. Frontiers in Psychology, 12 https://doi.org/10.3389/fpsyg.2021.678952

11. Salcido, C. G., Ray, J. V., Caudy, M., Viglione, J., \& Walter, R. J. (2019). Associations between psychopathic traits and readiness for change: An exploratory analysis. Personality and Individual Differences, 141, 86-91. https://doi.org/10.1016/j.paid.2018.12.021

12. Weigold, I. K., Weigold, A., Russell, E. J., Wolfe, G. L., Prowell, J. L., \& Martin-Wagar, C. A. (2020). Personal growth initiative and mental health: A metaanalysis. Journal of Counseling and Development, 98(4), 376-390. https://doi.org/10.1002/jcad.12340

13. Zaman, S., \& Naqvi, I. (2020). Translation and validation of personal growth initiative scale-II for pakistani adults. Pakistan Journal of Psychological Research, 35(4), 657-674. https://doi.org/10.33824/PJPR.2020.35.4.35

14. Стояцька Г. (2021). Особливості детермінації готовності до змін серед майбутніх українських правоохоронців. Психологічні перспективи/ Psychological Prospects. № 37. 2021. C. 214-232. https://doi.org/10.29038/22271376-2021-37-214-232

15. Наказ МВС України (2019). «Про вдосконалення підготовки курсантів у закладах вищої освіти із специфічними умовами навчання, які здійснюють підготовку поліцейських за спеціальністю «Правоохоронна діяльність» № 427 від 30.05.2019 р.

16. Наказ МВС України (2021). «Про підготовку фахівців у закладах вищої освіти із специфічними умовами навчання, які здійснюють підготовку поліцейських за освітньо-професійною програмою "2 роки курсант - 1 рік слухач”» № 615 від 18.08.2021 p.

\section{Referenses}

1. Ahmad, A. B., Liu, B., \& Butt, A. S. (2020). Scale development and construct clarification of change recipient proactivity. Personnel Review, 49(8), 1619-1635. https://doi.org/10.1108/PR-02-2019-0091

2. Augustsson, H., Richter, A., Hasson, H., \& von Thiele Schwarz, U. (2017). The need for dual openness to change: A longitudinal study evaluating the impact of employees' openness to organizational change content and process on intervention outcomes. Journal of Applied Behavioral Science, 53(3), 349-368. https://doi.org/10.1177/0021886317691930

3. Encouragement: The essential element of helping. (2019). Adlerian counseling and psychotherapy: A Practitioner's wellness approach, sixth edition (pp. 84-114) https://doi.org/10.4324/9781351038744

4. Jungers, C., \& Gregoire, J. (2021). Confrontation: A dialectical humanistic consideration. Journal of Humanistic Counseling, 60(1), 58-75. https://doi.org/10.1002/johc.12151

5. Knight, D. K., Joe, G. W., Becan, J. E., Crawley, R. D., Theisen, S. E., \& Flynn, P. M. (2019). Effectiveness of an intervention for improving intrinsic motivation among adolescent males in a secure substance use treatment 
setting. Criminal Justice and Behavior, 46(1), 101-114. https://doi.org/10.1177/0093854818804857

6. Myklebust, T., Motland, K., Garnås, A., Bjørklund, R., Bjørkli, C., \& Fostervold, K. I. (2020). An empirical evaluation of the relationship between human relations climate and readiness for change. Scandinavian Journal of Work and Organizational Psychology, 5(1), 1-12. https://doi.org/10.16993/SJWOP.74

7. Olafsen, A. H., Nilsen, E. R., Smedsrud, S., \& Kamaric, D. (2020). Sustainable development through commitment to organizational change: The implications of organizational culture and individual readiness for change. Journal of Workplace Learning, 33(3), 180-196. https://doi.org/10.1108/JWL-05-2020-0093

8. Peng, J., Li, M., Wang, Z., \& Lin, Y. (2021). Transformational leadership and employees' reactions to organizational change: Evidence from a metaanalysis. Journal of Applied Behavioral Science, 57(3), 369-397. https://doi.org/10.1177/0021886320920366

9. Qiao, S., Da, W., Li, X., Zhou, Y., \& Shen, Z. (2021). Occupational stress, burnout, and organizational readiness for change: A longitudinal study among HIV HCPs in china. Psychology, Health and Medicine, https://doi.org/10.1080/13548506.2021.1903059

10. Rehman, N., Mahmood, A., Ibtasam, M., Murtaza, S. A., Iqbal, N., \& Molnár, E. (2021). The psychology of resistance to change: The antidotal effect of organizational justice, support and leader-member exchange. Frontiers in Psychology, 12 https://doi.org/10.3389/fpsyg.2021.678952

11. Salcido, C. G., Ray, J. V., Caudy, M., Viglione, J., \& Walter, R. J. (2019). Associations between psychopathic traits and readiness for change: An exploratory analysis. Personality and Individual Differences, 141, 86-91. https://doi.org/10.1016/j.paid.2018.12.021

12. Weigold, I. K., Weigold, A., Russell, E. J., Wolfe, G. L., Prowell, J. L., \& Martin-Wagar, C. A. (2020). Personal growth initiative and mental health: A metaanalysis. Journal of Counseling and Development, 98(4), 376-390. https://doi.org/10.1002/jcad.12340

13. Zaman, S., \& Naqvi, I. (2020). Translation and validation of personal growth initiative scale-II for pakistani adults. Pakistan Journal of Psychological Research, 35(4), 657-674. https://doi.org/10.33824/PJPR.2020.35.4.35

14. Stoyatska G. (2021). Determination peculiarities of readiness for changes among future Ukrainian law enforcement officers. Psychological Prospects Journal, (37), 214-232. https://doi.org/10.29038/2227-1376-2021-37-214-232 [in Ukrainian].

15. Nakaz MVS Ukrainy (2019). «Pro vdoskonalennia pidhotovky kursantiv u zakladakh vyshchoi osvity iz spetsyfichnymy umovamy navchannia, yakizdiisniuiut pidhotovku politseiskykh za spetsialnistiu «Pravookhoronna diialnist» [Order of the Ministry of Internal Affairs of Ukraine "On improving the training of cadets in higher education institutions with specific training conditions, which train police officers in the specialty" Law Enforcement "] No 427 vid 30.05.2019 r. [in Ukrainian]. 
16. Nakaz MVS Ukrayiny (2021). «Pro pidhotovku fakhivtsiv u zakladakh vyshchoyi osvity iz osoblyvymy umovamy navchannya, yaki zdiysnyuyut' pidhotovku politseys'kykh za osvitn'o-profesiynoyu prohramoyu «2 roky kursant - 1 rik slukhach»»» [Order of the Ministry of Internal Affairs of Ukraine "On the training of specialists in higher education institutions with specific training conditions that train police officers under the educational and professional program "2 years cadet 1 year student"] No 615 vid 18.08.2021 r. [in Ukrainian].

Received: 01.11.2021 Accepted: 20.11.2021 